\title{
Analysis of Institutional Solid Waste Generation and Disposal in Afaka Military Cantonment Kaduna
}

\author{
Muktar Muhammad Namadi ${ }^{*}$, Afeez Oyeshola Jimoh \\ Department of Chemistry, Nigerian Defence Academy, Kaduna, Nigeria \\ Email address: \\ mmnamadi@nda.edu.ng (M. M. Namadi), hafeezmemo@gmail.com (A. O. Jimoh) \\ ${ }^{*}$ Corresponding author
}

\section{To cite this article:}

Muktar Muhammad Namadi, Afeez Oyeshola Jimoh. Analysis of Institutional Solid Waste Generation and Disposal in Afaka Military Cantonment Kaduna. International Journal of Environmental Protection and Policy. Vol. 8, No. 5, 2020, pp. 100-104.

doi: $10.11648 /$ j.ijepp.20200805.12

Received: September 12, 2020; Accepted: September 25, 2020; Published: October 13, 2020

\begin{abstract}
One of the key stages in developing sound institutional solid waste management plan is the accurate determination of the amount and characterization of the wastes generated in an organization. The aim of this study was to quantify and characterize the waste generated in Afaka Military cantonment of the Nigerian Defence Academy Kaduna. The survey covered 8 departments, a cadet's mess and an equitation wing and totalled 280 samples. The data for this study were obtained from field measurements and interview using structured questionnaire. The results obtained in the cadets' mess showed food waste recorded the highest amount of waste generated having $822.9 \mathrm{~kg} /$ day which represent $59 \%$. This was followed by ash and slaughter house waste with $18 \%$ and $16 \%$ respectively. The ash was a product of biomass burning as a result of cooking breakfast, lunch and dinner using a traditional three stone setting as means of cooking, while the waste from the slaughter house includes, skin offcut, cow dungs, blood, horns etc. Other results obtained for the components of wastes generated in the cadet's mess includes plastic waste (3\%), paper (2\%) and green waste (vegetable offcuts, potato peels, yam feels etc.) $(2 \%)$. The total quantity of waste generated from the cadets' mess was estimated at $1392.5 \mathrm{~kg} / \mathrm{day}$. The results show an increased per capita waste generation of $0.87 \mathrm{~kg} /$ day which is above the national average of $0.5 \mathrm{~kg} / \mathrm{day}$. Results from the study shows that at least $73 \%$ of the waste from the cantonment can be diverted from going to dumpsite. This amount can be recycled, reused, or used as an energy source. It also revealed that the major recyclable components that have significant presence are plastic, paper, yard waste, and food waste. In conclusion, recycling program in the military cantonment is highly recommended.
\end{abstract}

Keywords: Solid Waste, Generation, Disposal, Military Cantonment

\section{Introduction}

Sustainable development has forced developing countries to have a focused look at their waste management system including educational institutions. Solid waste management is the most pressing environmental challenge faced by urban and rural areas of Nigeria as well as its academic institutions [1]. Despite a host of policies and regulations, solid waste management in the country is assuming alarming proportions with each passing day. Adopting zero-waste policy among educational institutions have been shown to be achievable but requires full scale cooperation. Mason et al., evaluated the zero-waste program and environmental management structures at Massey University campus, New Zealand. The study showed that linkage between all involved sectors is needed to have a successful program and exhibited the necessity of including a formal waste management system [2] Armijo de Vega et al., conducted similar work and presented the development of a recycling program at the Autonomous University of Baja California. The study concluded that such programs require the involvement of different parties at the different levels within the University [3]. Sustainable and integrated solid waste management plan incorporating fully developed recycling programs at institutional level becomes an obvious need. Generally, educational institutions in developing countries such as Nigeria are running their solid waste management programs individually or with huge reliance on the government. A reference framework for solid waste management in educational institutions is therefore needed [4]. Currently, recycling is one of the profound 
measures the universities can take to show commitment to environmentally sound practices [4]. However, such plan requires comprehensive data on present and anticipated waste generation situation to build knowledge and estimate capacity to develop satisfactory plans and systems [5]. Waste characterization is a fundamental component in any municipal waste management scheme (MWMS). Waste characterization data consists of information on the types and amounts of materials (paper, food waste, glass, yard waste, etc.) in the waste stream. It depends on a number of factors such as food habits, cultural tradition, socioeconomic and climatic conditions. Treatment methods differ in dealing with different waste streams $[6,7]$. Options include recycling, land filling, biological treatment (i.e. composting and gasification), and thermal treatment such as mass burn incineration (with or without energy recovery) and fuel burning (Refuse Derived Fuels-RDF) [8]. The unsanitary mode of disposal of wastes, such as the dumping of refuse in pits, rivers and drainage channels could be expected to affect surface and groundwater quality [9]. Hence, the management and control of wastes at all stages of production, collection, transportation, treatment and ultimate disposal is a relatively social imperative [10]. Little documentation of the quantity and composition of wastes generated in different areas of African cities, are limiting the capacity to develop effective waste management systems [11]. Obviously, institutions in
Nigeria are not exempted from the problem of solid waste generation and management. Based on these concerns, this paper sets out to characterize and quantify the solid wastes generated in Afaka Military Cantonment Kaduna, in order to provide reliable data on the sources, types, composition and rate of generation of wastes for the implementation of sound waste management system.

\section{Materials and Methods}

\subsection{Study Areas}

This study was conducted in different locations within the Nigerian Defence Academy, Afaka Military Cantonment, Kaduna. These locations include: Cadet Mess, Equitation and Faculties of Sciences and Engineering as shown in Figure 1.

Figure 1 shows the satellite imagery of the study area, which is Afaka Military Cantonment, Kaduna.

A reconnaissance study was undertaken to map out strategies for field work and to identify various sources of solid waste. The aim of which is to identify possible sampling techniques best suited for the research work, the data for this study were obtained directly from the field through observation, field surveys and use of well-structured questionnaire.

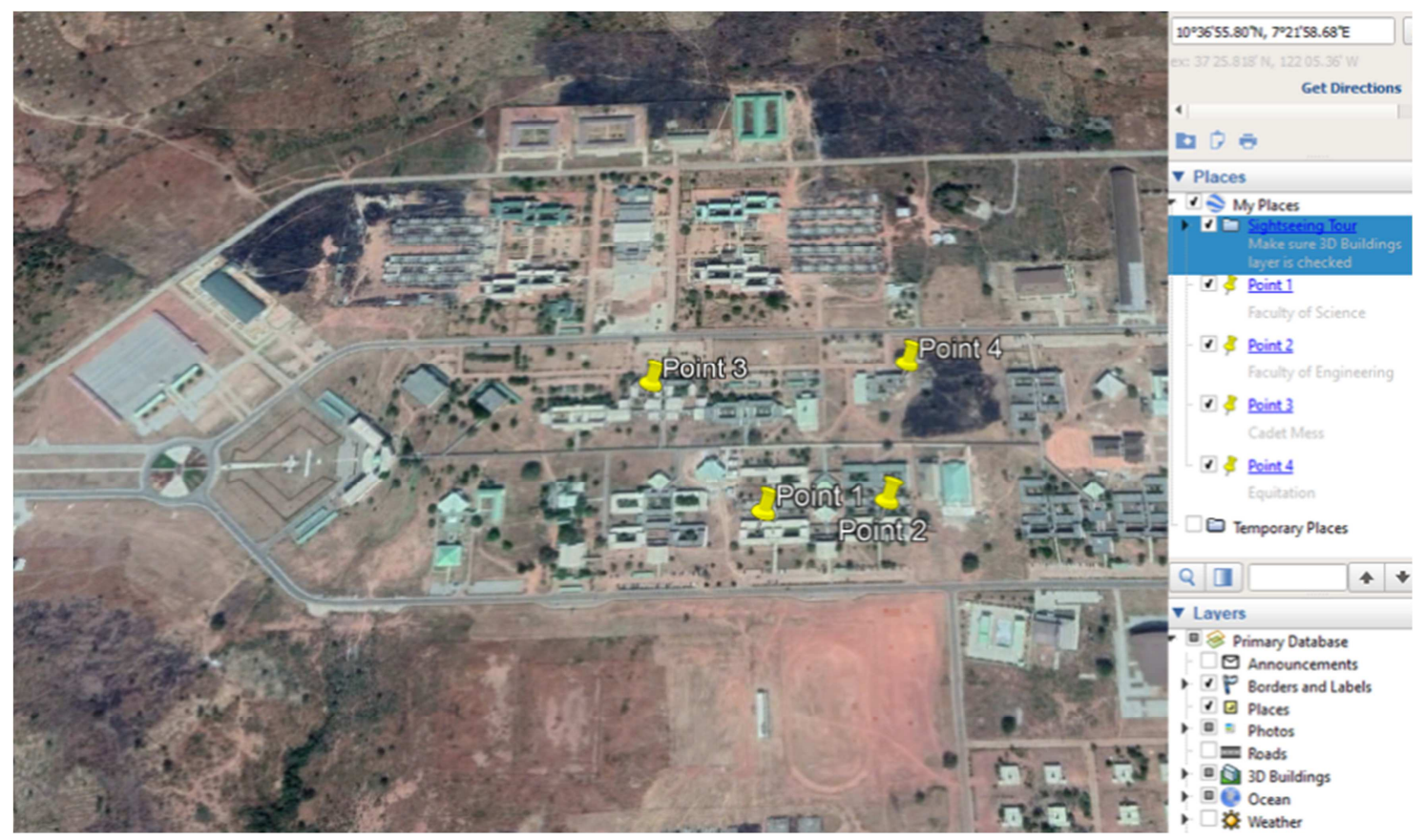

Figure 1. Map of Study Area.

\subsection{Sorting Procedure}

Two bins/polythene bags were supplied to each collection venue for the sorting and separation, to organic wastes and all other waste.

The organic waste bin was labelled "Biodegradables except paper" which will include food/kitchen waste, leaves, tree branches, wood waste, and agricultural waste while the
"Other wastes" bin will comprise of plastics, papers, textiles, metals, glass, rubber, leather and any waste which cannot be classified. Initial sorting of the waste was carried out by members producing the waste and further sorting was done by the research team. The sorted wastes were weighed using balances.

The waste characterization study was carried out for five days on each of the study area and the average of wastes 
taken in $\mathrm{kg}$ per day, to even out encountered irregularities in the waste generations. These monitoring was carried out over a period of 2 months (December 2016 to February 2017).
The percentage composition of each of the components were calculated using the formula:

$$
\text { Percentage composition of waste fraction }=\frac{\text { Weight of separated } \text { waste }}{\text { The total of mixed waste sampled }} \times 100
$$

\section{Results and Discussion}

Table 1 shows the result of the composition of waste in the cadets' mess. The cadet mess also referred to as the kitchen prepares and serves food for about 1,500 cadets and about 100 security guards in the cantonment. The results obtained reveals that higher amount of waste was generated from food wastes (59\%) as shown in Figure 2. 17\% was obtained for ash. This is because firewood is the major source of fuel used for cooking while, $11 \%$ was obtained for the wastes of slaughtered cow. These wastes include, cow dungs, blood, horns, water etc. Other results obtained for the components of wastes generated in the cadets' mess includes nylon (3\%), paper $(2 \%)$, grass $(2 \%)$, firewood waste $(1 \%)$ and gutter rubbish $(5 \%)$. The total quantity of waste generated from the cadets' mess is estimated at $1392.5 \mathrm{~kg} /$ day.

The results obtained in this study is in line with previous study of Amori et al., where they revealed that food wastes constitute the highest proportion of wastes generated (46\%) from the halls of residence in the University of Lagos, Obafemi Awolowo University and University of Ibadan [12]. The other waste materials generated include; plastic 5\%, paper $4 \%$, sanitary wastes and hairs $6 \%$ each, sand $7 \%$, cans/tins $2 \%$, e-waste, textiles and glass $1 \%$ each, while other unclassified components were $8 \%$.

Table 1. Composition of Wastes from the Cadet Mess.

\begin{tabular}{ll}
\hline Components & Total Quantity of wastes (kg/day) \\
\hline Ash & 234 \\
Nylon & 39.6 \\
Paper (Carton) & 25 \\
Food waste & 822.9 \\
Grass & 25 \\
Fire Wood Waste & 23 \\
Gutter Rubbish (Mix) & 68 \\
Cow Dungs + Horn + Water & 155 \\
Total & 1392.5 \\
\hline
\end{tabular}

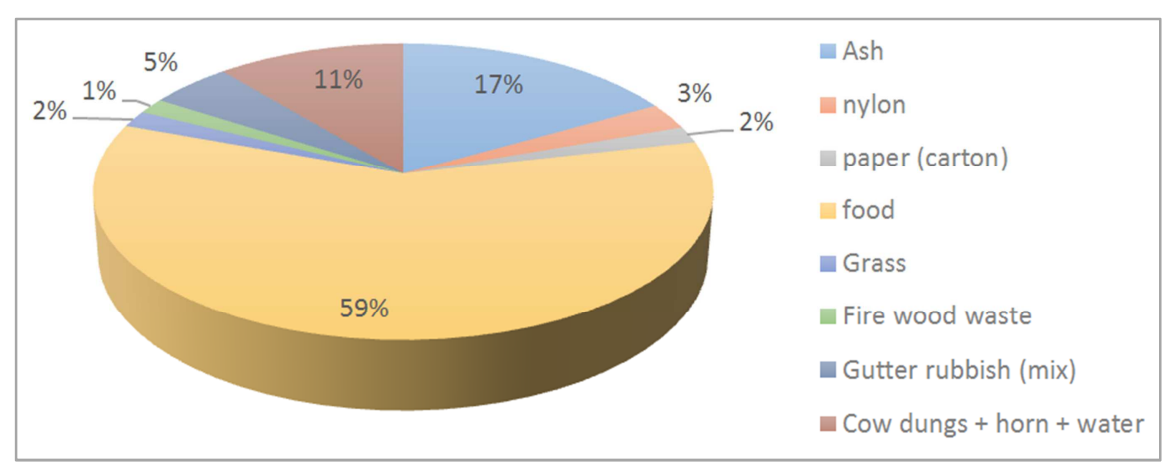

Figure 2. Percentage Composition of waste from the cadet mess.

Table 2 shows the result of the composition of waste from the faculties of science and engineering. The results obtained revealed that higher amount of waste was generated from papers and plastics (38\%). Other wastes include nylon (19\%), can $(3 \%)$ and yard wastes $(2 \%)$ as shown in Figure 3 . The total quantity of waste generated from the faculties is estimated at $316.3 \mathrm{~kg} /$ day.

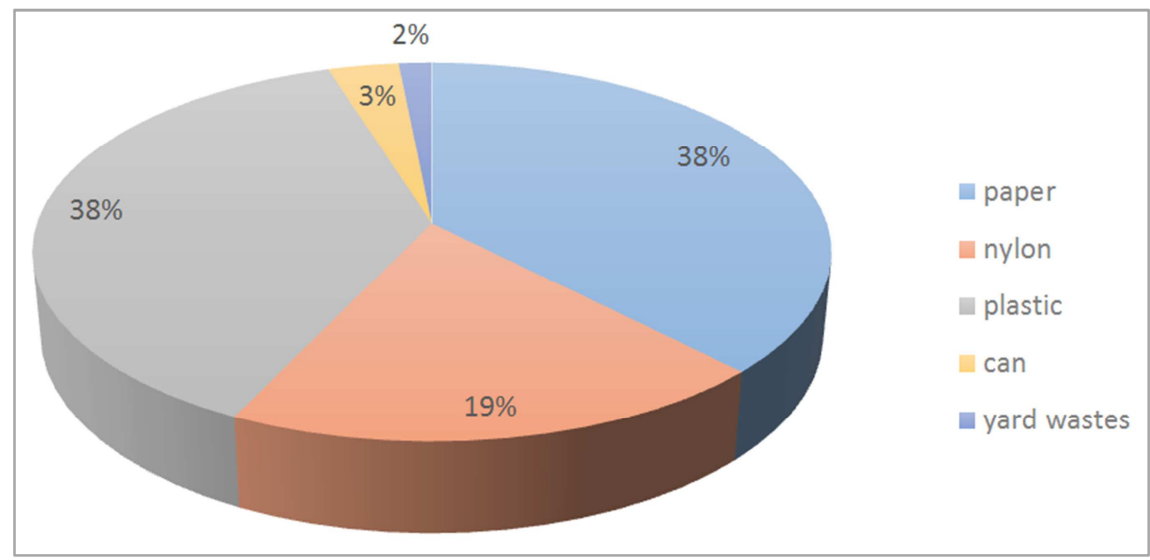

Figure 3. Percentage Composition of waste from faculties of science and engineering. 
Table 2. Composition of Wastes from Faculties of Science and Engineering.

\begin{tabular}{ll}
\hline Components & Total Quantity of wastes $\mathbf{( k g / d a y )}$ \\
\hline Papers & 119.2 \\
Nylons & 61.4 \\
Plastics & 120.3 \\
Cans & 10.5 \\
Yard wastes & 4.9 \\
Total & 316.3 \\
\hline
\end{tabular}

Table 3 shows the result of the composition of waste from the equitation. The equitation has about 50 horses. The results obtained revealed that higher amount of waste was generated from horse dungs $(67 \%)$. While $33 \%$ was obtained from grass remains in the stable. The total quantity of waste generated from the equitation is estimated at $600.6 \mathrm{~kg} /$ day.

Table 3. Composition of Wastes from the Equitation.

\begin{tabular}{ll}
\hline Components & Total Quantity of wastes $(\mathbf{k g} /$ day) \\
\hline Horse Dungs & 400.6 \\
Grasses & 200 \\
Total & 600.6 \\
\hline
\end{tabular}

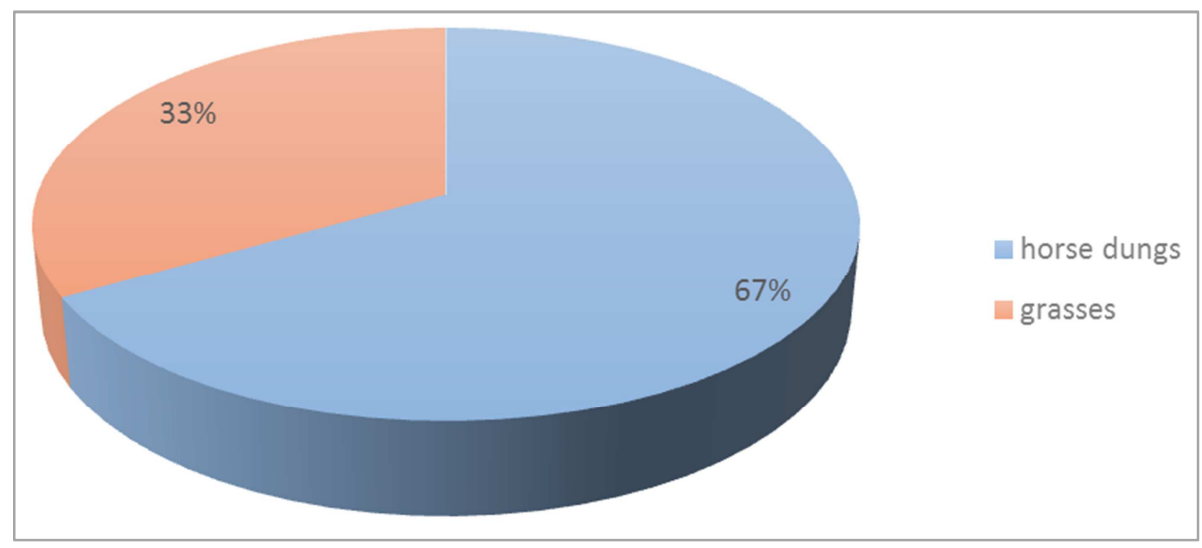

Figure 4. Percentage Composition of waste from the equitation.

Figure 5 shows the percentage of waste composition generated in the cantonment. It shows that $36 \%$ of the wasted generated are wood wastes while $17 \%$ is from the horse dungs. Other results obtained include ash $(10 \%)$, grass $(10 \%)$, paper $(6 \%)$, plastics $(5 \%)$, nylon $(4 \%)$, and cans $(1 \%)$.

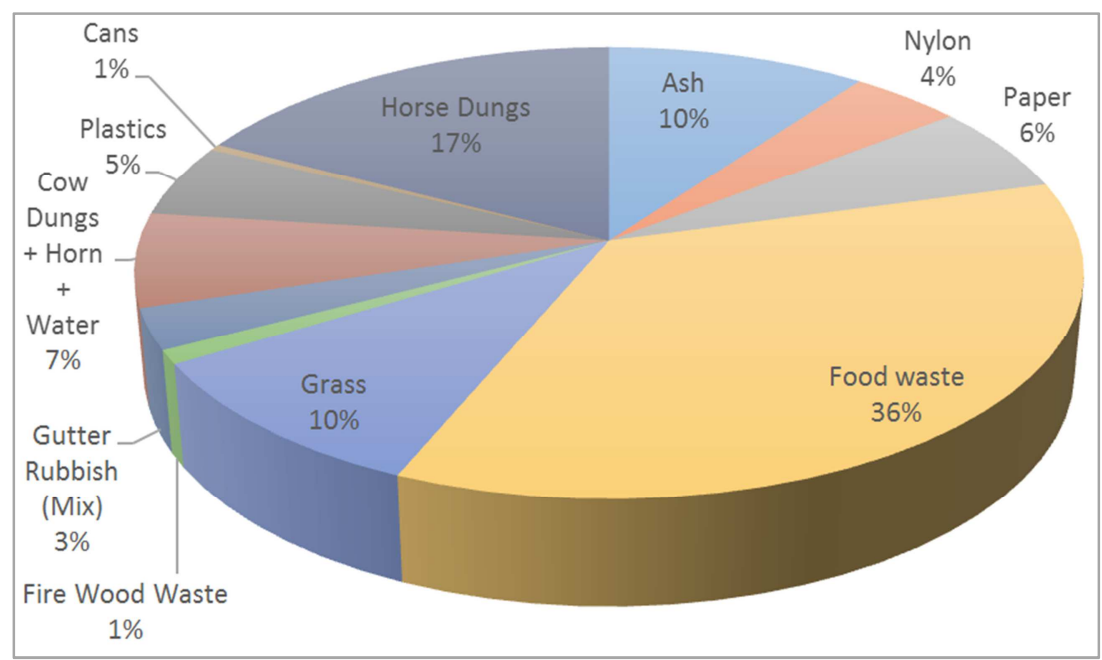

Figure 5. Percentage Composition of waste generated in the Cantonment.

\section{Conclusion}

The study showed that waste generated from the Afaka Military Cantonment reaches an average of $1392.5 \mathrm{~kg} /$ day. The study presented that at least $73 \%$ of the waste stream from the cantonment can be diverted from going to dumpsite. This amount can be recycled, reused, or used as an energy source. The study revealed that the major recyclable components that have significant presence are plastic, paper, yard waste, and food waste. The study results showed that recycling program in the military cantonment is highly recommended but requires full scale cooperation and careful handling. The largest proportion of waste in the cantonment can be composted or converted to biogas rather than disposed of which is the current practice. The result suggests the need to establish a formal composting of the biodegradable wastes and recycling facilities for others which cannot be composted within the academy. Efforts should be made within the 
cantonment to evolve policies for disposal, waste reduction and recycling project. There should also be joint participation within all area of the academy and involvement in waste management.

\section{References}

[1] Bakare, W. (2019). Solid Waste Management in Nigeria. Bioenergy Consult-Powering Clean Energy Future. https://www.bioenergyconsult.com/solid-waste-nigeria/.

[2] Mason, I., Brooking, A., Oberender, A., Hardford, J., and Horsley, P., (2003). Implementation of a zero waste program at a university campus. Resources, Conservation, and Recycling. 38: 257-269.

[3] Armijo de Vega, C., Benitez, S., and Ramirez-Barreto, M., (2003). Mexican educational institutions and waste management programmes: A University case study. Resources, Conservation, and Recycling, 39: 283-296.

[4] Armijo de Vega C., Benítez S., Ramirez-Barreto, M., (2008). Solid waste characterization and recycling potential for a university campus. Waste Management. 28: S21-S26.

[5] UNEP (United Nations Environment Programme), (2009). Developing Integrated Solid Waste Management Plan: Training Manual, Volume 4. ISWM Plan.
[6] Gawaika V. (2004), Source Specific Quantification and Characterization of Municipal Solid Waste - a Review. IE (I) Journal-EN Vol 86.

[7] Jarusombat S. (2002). Factors influencing treatment decisions of hazardous waste generators: A case study of factories in the Bangkok region. Waste Management and Research, 20 (6): 125-133.

[8] Babcock, C and Wilcox V. (2003). Computational Fluid Dynamics in Waste-to-Energy Technology. Pamphlet.

[9] Sangodoyin, A. Y. (1991). Ground and Surface Water Pollution by Open Dump in Ibadan, Nigeria. Discovery and Innovation. 2 (1): 37-43.

[10] Salami, L., Susu, A. A., Patinvoh, R. J. and Olafadehan, O. A. (2011). Characterization Study of Solid Wastes: A Case of Lagos State. International Journal of Applied Science and Technology, 1 (3): 47-52.

[11] Afon, A. O. (2007). An Analysis of Solid Waste Generation in Traditional African City, the Example of Ogbomosho, Nigeria. Environment and Urbanization, 19: 527-537.

[12] Amori, A. A, Fatile B. O, Ihuoma, S. O and Omoregbee, H. O. (2013). Waste Generation and Management Practices in Residential Areas of Nigerian Tertiary Institutions. Journal of Educational and Social Research. 3 (4): 45-51. 